\title{
Wojna hybrydowa jako przykład umiędzynarodowionego konfliktu wewnętrznego ${ }^{1}$
}

\section{Wprowadzenie}

Pojęcie wojny hybrydowej ${ }^{2}$ stało się w ostatnich latach niezwykle popularne ${ }^{3}$. Najczęściej kojarzony z tym zjawiskiem jest trwający od $2014 \mathrm{r}$. konflikt zbrojny na Ukrainie ${ }^{4}$, który w wielu miejscach różni się od klasycznego konfliktu międzynarodowego ${ }^{5}$. O agresję na terytorium

${ }^{1}$ Praca naukowa finansowana ze środków budżetowych na naukę w roku 2017 jako projekt badawczy pt. "Wojny hybrydowe i ich implikacje dla postzimnowojennego ładu międzynarodowego" w ramach programu MNiSW „Diamentowy Grant”, prowadzony na Uniwersytecie Jagiellońskim pod kierownictwem Pawła Ochmanna.

${ }^{2}$ Wojna hybrydowa może być, oczywiście, zarówno międzynarodowym, jak i niemiędzynarodowym konfliktem zbrojnym, w niniejszym artykule analizie poddana zostaje zatem tylko jedna z możliwych konfiguracji wojny hybrydowej, gdzie konflikt wewnętrzny o cechach hybrydowych ulega umiędzynarodowieniu.

${ }^{3}$ Nie jest to jednak bynajmniej pojęcie zupełnie nowe. Łączone bywa ono niekiedy z pojęciem "asymetryczności”. Zob. Asymetria i hybrydowość - stare armie wobec nowych konfliktów, pod red. W. Sokały, B. Zapały, Kielce 2011.

${ }^{4}$ Potwierdzeniem łączenia anarchii panującej we wschodniej Ukrainie z pojęciem wojny hybrydowej i jednocześnie wyrazem wspomnianego już wzrostu popularności tego pojęcia w ostatnim czasie mogą być niedawno opublikowane monografie na ten temat. Zob. B. Pacek, Wojna hybrydowa na Ukrainie, Warszawa 2018; Konflikt hybrydowy na Ukrainie. Aspekty teoretyczne i prawne, pod red. B. Packa, J.A. Grochockiej, Piotrków Trybunalski 2017; B. Pacek, J.A. Grochocka, Wojna hybrydowa na Ukrainie. Wnioski i rekomendacje dla Rady Europy i świata, Piotrków Trybunalski 2017; Międzynarodowe konsekwencje konfliktu zbrojnego na Ukrainie, pod red. T. Kubaczyka, S. Piotrowskiego, M. Żyły, Warszawa 2016.

${ }^{5}$ Zob. B. Pacek, P. Pacek, Specyfika wojny hybrydowej na Ukrainie, w: Wojna hybrydowa na Ukrainie. Wnioski i rekomendacje, pod red. B. Packa i J.A. Grochowskiej, op. cit. 
Ukrainy jest bowiem powszechnie oskarżana Federacja Rosyjska ${ }^{6}$, oficjalnie nieprzyznająca się do tego, która w dodatku jest zdania, że walki na wschodzie tego kraju prowadzone są wyłącznie przez miejscowych powstańców (separatystów). Świat zachodni oskarża jednak Moskwę nie tylko o wspieranie tych grup, ale również o sprawowanie nad nimi kontroli, a także współdziałanie z nimi regularnych jednostek armii rosyjskiej.

Badacze stosunków międzynarodowych wskazują w takich sytuacjach na wiele cech składających się na tworzone definicje wojny hybrydowej. Na wstępie należy bowiem zaznaczyć, że "wojna hybrydowa” nie jest pojęciem prawnym. Jako metoda prowadzenia walki charakteryzuje się ona określonymi cechami, spośród których różne są eksponowane przy tworzeniu określonych definicji. Inaczej jednak wygląda kwalifikacja prawna takich konfliktów, odbywająca się przy klarownym podziale na konflikty międzynarodowe i niemiędzynarodowe (wewnętrzne). Jest ona o tyle ważna, że chociaż wojna hybrydowa jest pojęciem pozaprawnym, to działania, jakie mają miejsce w jej trakcie, muszą być oceniane pod kątem prawa. Ta ocena ma decydujące znaczenie przy ewentualnym pociągnięciu państwa do odpowiedzialności za naruszenie prawa międzynarodowego. Jedną z immanentnych cech wojen hybrydowych może być jednak chęć uniknięcia przez państwo właśnie tej odpowiedzialności i zakamuflowania swoich działań. Tym samym agresor będzie wykorzystywać te instrumenty, które najlepiej pozwolą zrealizować tenże cel. Dlatego też pożądane wydaje się uchwycenie słabości systemu prawa międzynarodowego, którymi może posłużyć się państwo prowadzące wojnę hybrydową.

Zdaniem autorów niniejszego opracowania wiele celów wojny hybrydowej, w tym możliwość uniknięcia odpowiedzialności międzynarodowej za działania agresywne, może być zrealizowanych w trakcie umiędzynarodowionego konfliktu wewnętrznego. Celem tego artykułu jest tym samym zweryfikowanie powyższej hipotezy poprzez zestawienie ze sobą cech wojny hybrydowej z kryteriami kwalifikującymi dany konflikt zbrojny jako umiędzynarodowiony konflikt wewnętrzny, a także normami prawnymi obowiązującymi w takich warunkach. Pozwoli to na określenie słabości obecnego systemu prawa międzynarodowego,

${ }^{6}$ Zob. K. Parulski, Ocena działań hybrydowych Federacji Rosyjskiej w konflikcie na Ukrainie w świetle prawa krajowego i międzynarodowego. Historyczne prawa do terytorium, w: Wojna hybrydowa na Ukrainie. Wnioski i rekomendacje, pod red. B. Packa i J.A. Grochowskiej, op. cit. 
a jednocześnie ukazanie całego spektrum działań państwa wykorzystującego metody hybrydowe w trakcie umiędzynarodowionego konfliktu wewnętrznego.

Realizacja tak ustalonego celu będzie wiązać się ze zdefiniowaniem obydwu pojęć: wojny hybrydowej i umiędzynarodowionego konfliktu wewnętrznego. Następnie to ostatnie zjawisko zostanie opisane szerzej, ze szczególnym uwzględnieniem niejasności i luk obowiązujących w takiej sytuacji norm prawa międzynarodowego, które mogą być wykorzystane przez państwo posługujące się metodami hybrydowymi ${ }^{7}$. Niniejsza praca opiera się na licznych publikacjach zarówno polskich, jak i zagranicznych. Warto jednak nadmienić, że spojrzenie na zjawisko wojen hybrydowych pod kątem kryteriów umiędzynarodowionego konfliktu wewnętrznego dotąd nie było podejmowane.

\section{Pojęcie wojny hybrydowej}

Po raz pierwszy zjawisko określane mianem wojny hybrydowej zdefiniował Jewgienij Messner - pułkownik armii "białej Rosji”, który w latach sześćdziesiątych XX w. stworzył pojęcie "wojen buntowniczych". Badacz ten wychwycił wówczas wszystkie cechy, na które zwrócono uwagę dopiero prawie pięć dekad później. Wojny buntownicze, zdaniem Messnera, charakteryzują się stanem rozmycia między pokojem a wojną. Oznacza to, że agresor podejmuje działania, które dziś noszą miano operacji poniżej progu wojny - drobnych starć, które mają przede wszystkim za zadanie zdestabilizować sytuację wroga, powodować poczucie chaosu i pogarszać nastroje społeczne.

Czynnik psychologiczny odgrywa tutaj zresztą decydującą rolę. Celem strony walczącej powinno być bowiem złamanie morale przeciwnika i przeciągnięcie na swoją stronę przynajmniej części jego społeczeństwa. Messner zwracał uwagę na możliwość wspierania ruchów rozłamowych $w$ ramach państwa przeciwnika, osób niezadowolonych z tamtejszych władz czy mniejszości narodowych. Powoduje to w konsekwencji, że w wojnie buntowniczej właściwa linia frontu się zaciera.

${ }^{7}$ Metody te mogą mieć rozmaity charakter, co pozwala na umiejętne ich wykorzystanie do okoliczności konkretnej sytuacji. Por. O. Wasiuta, Militarne i niemilitarne metody prowadzenia wojny hybrydowej Rosji przeciwko Ukrainie, w: Wojna hybrydowa na Ukrainie. Wnioski i rekomendacje, pod red. B. Packa i J.A. Grochowskiej, op. cit. 
Z tego też względu pułkownik ogromną wagę przywiązywał do wojny informacyjnej, jako cennego czynnika destabilizacji, otwierającego możliwość wywołania buntu na tyłach sił przeciwnika ${ }^{8}$.

Autor ten zaznaczał zarazem, że zaangażowanie poszczególnych grup społecznych w konflikt może doprowadzić do zatarcia się granicy między przedstawicielami sił zbrojnych a cywilami. Działania zbrojne maja przez to charakter przede wszystkim nieregularny. Rzeczywisty agresor może z kolei prowadzić konflikt przez swoistego pośrednika, którym będą luźno z nim powiązane grupy zbrojne. W trakcie wojny buntowniczej dochodzi również do przeprowadzenia licznych operacji o charakterze specjalnym, jak dywersja czy działania pod obcą flagą. Oczywiście, dywersja czy operacje specjalne nie są prowadzone tylko w czasie wojny buntowniczej, gdyż spotyka się je praktycznie w każdej formie konfliktu. Jednakże zaryzykować można twierdzenie, że w czasie wojny buntowniczej dywersja zyskuje na znaczeniu, a jej udział jako metody prowadzenia działań w konflikcie jest większy. Stąd można uznać dywersję (a dokładniej, stopień jej intensyfikacji) za element wyróżniający. Kolejną ważną konsekwencją wojny buntowniczej, którą wskazuje się jako cechę charakterystyczna, jest zatarcie granicy między tym, co legalne, a tym, co bezprawne, w związku z czym trudno przypisać odpowiedzialność państwu za bezprawne działania9.

Warto jednak zaznaczyć, że powyżej wskazane cechy były wykorzystywane już od dawna. Sam Messner opierał się w swoich badaniach na osobistych doświadczeniach wyniesionych z czasów wojny domowej w Rosji. Natomiast już w VI w. p.n.e. chiński strateg Sun Tzu postulował wykorzystanie w trakcie prowadzenia konfliktu takich metod, jak podstęp wojenny, działania wywiadowcze, operacje z zaskoczenia, czy też zabiegi łamiące wolę walki przeciwnika ${ }^{10}$. Jako starożytny przykład wojny hybrydowej wskazuje się często wojnę peloponeską (431-404 p.n.e. $)^{11}$.

${ }^{8}$ J.E. Miessnier, Miatież - imia trietjej wsiemirnoj, w: idem, Choczesz mira, pobiedi miatieżewojnu!, Tworczeskoje nasledije J.E. Miessniera, Moskwa 2005, s. 133 i n.

9 J.E. Miessnier, Wsiemirnaja miatieżewojna, Żukowskij-Moskwa 2004, s. 136, 214220; K. Kraj, Wojny asymetryczne czy miatieżewojna Jewogienija Messnera zagrożeniem dla bezpieczeństwa w XXI wieku, „Bezpieczeństwo. Teoria i Praktyka” 2012, nr 3, s. 33-39; L. Sykulski, Wojny buntownicze - wprowadzenie do koncepcji Jewogienija Messnera, "Przegląd Geopolityczny" 2015, nr 11, s. 103-111.

${ }^{10}$ Sun Tzu, Sun Pin, Sztuka wojny, Gliwice 2004, s. 60-62 i in.; J. Regina-Zacharski, Ukraina 2014-2015: wojna (nie)hybrydowa, "Zeszyty Naukowe AON" 2015, nr 3(100), s. 34-35.

${ }^{11} \mathrm{~K}$. Wąsowski, Istota i uniwersalność rosyjskiego modelu wojny hybrydowej, "Sprawy Międzynarodowe" 2015, nr 2, s. 40. 
Współczesne badania nad wojnami hybrydowymi zostały zapoczątkowane po wojnie lipcowej z 2006 r. między Izraelem a Libanem. W literaturze anglojęzycznej można wskazać dwie najczęściej przywoływane definicje tego typu konfliktów. W. Williamson Murray i P.R. Mansoor w swojej pracy poświęconej historii wojen hybrydowych określają je jako „konflikt obejmujący użycie regularnych sił zbrojnych i oddziałów nieregularnych (o charakterze partyzanckim, powstańczym lub terrorystycznym), w którym uczestniczyć mogą państwa i aktorzy pozapaństwowi, a ich działania skupiają się na osiągnięciu spójnego politycznego celu"12.

Warto zwrócić uwagę na występowanie obok siebie oddziałów regularnych i nieregularnych oraz istnienie spójnego celu politycznego. Natomiast status prawny strony (państwo/aktor niepaństwowy) ma tutaj drugorzędne znaczenie. Tym samym może to powodować, że pojęcie wojny hybrydowej może obejmować większość konfliktów zbrojnych ${ }^{13}$. Działanie obok siebie oddziałów regularnych i nieregularnych w imię spójnego celu politycznego występowało niezwykle często w historii konfliktów zbrojnych. Natomiast kwestie określenia statusu prawnego grup, które w obliczu napaści spontanicznie chwyciły za broń, unormowano już w regulaminie haskim z $1907 \mathrm{r}^{14}$

Bardziej rozpowszechnioną definicję wojny hybrydowej ukuł F.G. Hoffman. Zgodnie z nią jest to konflikt zbrojny, w którym przynajmniej jedna ze stron „równolegle stosuje unikalne połączenie użycia broni konwencjonalnej, nieregularnej taktyki działania, terroryzmu i działań o charakterze kryminalnym w ramach realizacji celów politycznych"15. W kontekście wspomnianego konfliktu izraelsko-libańskiego z 2006 r. badacz ten wskazywał, że można było tam zaobserwować takie elementy hybrydowe, jak walka podmiotu pozapaństwowego z państwem, przy wykorzystaniu potężnej machiny informacyjno-propagandowej, działań terrorystycznych i dywersyjnych oraz nowoczesnego sprzętu ${ }^{16}$. Często

${ }^{12}$ M. Williamson Murray, P.R. Mansoor, Hybrid Warfare: Fighting Complex Opponents from the Ancient World to the Present, Cambridge 2012, s. 2.

${ }^{13}$ Zważywszy zwłaszcza na przemiany, jakie nastąpiły w sposobie prowadzenia działań zbrojnych i sporów po II wojnie światowej. Zob. na ten temat np.: R. Łoś, J. Reginia-Zacharski, Wspótczesne konflikty zbrojne, Warszawa 2010, oraz K. Drabik, Tradycyjne rozumienie zjawiska wojny a charakter wspótczesnych konfliktów zbrojnych, w: Międzynarodowe konsekwencje...

${ }^{14}$ Konwencja dotycząca praw i zwyczajów wojny lądowej (Dz.U. 1927 Nr 21, poz. 161).

${ }^{15}$ F.G. Hoffman, Conflict in the 21st Century: The Rise of Hybrid Wars, Arlington 2007, s. 28; idem, On Not-So-New Warfare: Political Warfare vs. Hybrid Threats, https://warontherocks.com/2014/07/on-not-so-new-warfare-political-warfare-vs-hybrid-threats/ (dostęp: 2 IV 2018).

${ }^{16}$ Ibidem. 
wymienianym przez badaczy elementem wojny hybrydowej jest też kombinacja konwencjonalnych sił wojskowych oraz sił nieregularnych (partyzantów, rebeliantów lub terrorystów), przeprowadzanie operacji specjalnych dokonywanych na tyłach przeciwnika, a także wzmożona aktywność propagandowa czy przeprowadzanie ataków cybernetycznych.

Wymienione cechy składające się na definicję wojny hybrydowej występują także w innych znanych w dziedzinie stosunków międzynarodowych rodzajach konfliktów zbrojnych. Należy tutaj wymienić chociażby konflikt asymetryczny, w którym ścierają się strony o różnym potencjale, przy czym strona słabsza wykorzystuje działania o charakterze niekonwencjonalnym, terrorystycznym, niezgodne z przyjętymi zasadami prowadzenia konfliktu zbrojnego ${ }^{17}$. Innym konfliktem, w którym zawiera się wojna hybrydowa, jest konflikt nieregularny. Mamy z nim do czynienia, gdy co najmniej jedna ze stron jest aktorem niepaństwowym. Zbliżonym pojęciem jest wojna mieszana, czyli wykorzystanie w jedynym konflikcie przez co najmniej jedną stronę jednocześnie oddziałów regularnych i nieregularnych ${ }^{18}$.

Jednakże zbyt daleko idące łączenie wojny hybrydowej z konfliktem asymetrycznym może niekiedy prowadzić do traktowania tych pojęć jako określeń tych samych desygnatów. Przeciwko utożsamianiu wojny hybrydowej z konfliktem asymetrycznym zdaje się opowiadać A. Gruszczak. Podkreśla on, że asymetria potencjału niekoniecznie musi oznaczać nierównowagę strategiczną zaangażowanych podmiotów. Autor pisze, że "W podejściu do hybrydowości konfliktów zbrojnych błędem jest tworzenie dychotomii między statecznym państwem a zmiennym, elastycznym i amorficznym przeciwnikiem niepaństwowym"19.

\section{Konflikt wewnętrzny a wewnętrzne napięcia i niepokoje}

W potocznym rozumieniu konflikty wewnętrzne to nic innego jak wojny domowe ${ }^{20}$. Jednak na gruncie prawa międzynarodowego stosowanie samego określenia "wojna” zostało już w latach pięćdziesiątych XX w.

${ }_{17}$ A. Kleczkowska, Wojna hybrydowa - uwagi z perspektywy prawa międzynarodowego publicznego, "Sprawy Międzynarodowe” 2015, nr 2, s. 98.

${ }^{18}$ Ibidem.

${ }^{19}$ A. Gruszczak, Hybrydowość wspótczesnych wojen - analiza krytyczna, w: Asymetria i hybrydowość..., s. 16.

${ }^{20}$ Przykładów wojen domowych można wskazać w toku rozwoju historycznego wiele, jednym z nich - szczegółowo omówionym przez R. Łosia w kontekście cech 
zaniechane na rzecz szerszego pojęcia - „konfliktu zbrojnego"21. Tym samym konflikt wewnętrzny, zwany również niemiędzynarodowym, jest jedną z jego odmian.

W odróżnieniu od konfliktu międzynarodowego konflikt wewnętrzny charakteryzuje się toczącymi się starciami zbrojnymi między grupami wewnątrzkrajowymi. Jedną z nich najczęściej jest strona legalnego rządu. Z kolei strona rozłamowa w takim konflikcie nie jest uznawana przez społeczność międzynarodową za stronę wojującą ${ }^{22}$. Definicję konfliktu wewnętrznego znajdujemy w art. 1 ust. 1 Drugiego Protokołu Dodatkowego do Konwencji Genewskich dotyczącego ochrony ofiar niemiędzynarodowych konfliktów zbrojnych, przyjętego 8 czerwca 1977 r. $^{23}$ (II PD KG). Zgodnie z nim taki charakter mają walki między siłami zbrojnymi danego państwa a "rozłamowymi siłami zbrojnymi lub innymi zorganizowanymi uzbrojonymi grupami, pozostającymi pod odpowiedzialnym dowództwem i sprawującymi taką kontrolę nad częścią jej terytorium, że mogą przeprowadzać ciągłe i spójne operacje wojskowe oraz stosować niniejszy protokół".

Próby zdefiniowania konfliktu niemiędzynarodowego podjęła również Izba Apelacyjna Międzynarodowego Trybunału Karnego (MTK) do spraw zbadania zbrodni w byłej Jugosławii (MTKJ) w orzeczeniu Tadić. Trybunał uznał wtedy, że „z konfliktem zbrojnym mamy do czynienia zawsze, gdy dochodzi do użycia siły zbrojnej między państwami lub przedłużającego się konfliktu zbrojnego między władzami rządowymi a uzbrojonymi, zorganizowanymi grupami lub między takimi grupami

charakterystycznych, symptomatycznych dla tego rodzaju konfliktów - może być wojna domowa w Sudanie. Zob. R. Łoś, Konflikty w Sudanie, Warszawa 2013.

${ }^{21}$ Jako przyczynę tego zjawiska podaje się najczęściej skłonność państw do unikania nazywania swoich działań zbrojnych mianem "wojny”. Dlatego społeczność międzynarodowa dążyła do rozszerzenia prawa antywojennego na inne przejawy użycia siły przez państwa. Zob. R. Bierzanek, J. Symonides, Prawo międzynarodowe publiczne, Warszawa 2015, s. 379.

${ }^{22}$ Uznanie za stronę wojującą powinno nastąpić dopiero po spełnieniu pewnych warunków. Strona rozłamowa konfliktu wewnętrznego powinna sprawować w takim przypadku kontrolę nad pewnym terytorium, działać pod jednolitym dowództwem, przestrzegać praw i zwyczajów wojennych i być zdolna do nawiązania stosunków o ograniczonym charakterze dla obrony swoich interesów. Uznanie powoduje, że konflikt wewnętrzny przez państwo uznające jest traktowany jak konflikt międzynarodowy. Zob. W. Góralczyk, S. Sawicki, Prawo międzynarodowe w zarysie, Warszawa 2017, s. 159.

${ }^{23}$ Protokoły dodatkowe do Konwencji genewskich z 12 VIII 1949 r., dotyczące ochrony ofiar międzynarodowych konfliktów zbrojnych (Protokół I) oraz dotyczący ochrony ofiar niemiędzynarodowych konfliktów zbrojnych (Protokół II), sporządzone w Genewie dnia 8 VI 1977 r. (Dz.U. 1992 Nr 41, poz. 175). 
wewnątrz państwa"24. Kluczowy w tym miejscu jest element temporalny - "przedłużającego się konfliktu”. Obok intensywności starć pozwala on odróżnić wewnętrzny konflikt zbrojny od stanu wewnętrznych napięć i niepokojów, o których wspomina art. 1 ust. 2 II PD KG.

Wewnętrzne napięcia i niepokoje mają miejsce w sytuacji zamieszek czy demonstracji spowodowanych przez osoby bądź grupy osób, w czasie których dochodzi do sporadycznych aktów przemocy. Z perspektywy prawnej zastosowanie mają wówczas jedynie normy międzynarodowych praw człowieka oraz przepisy prawa krajowego. W praktyce może to oznaczać niekiedy podejmowanie działań, które byłyby niemożliwe w trakcie konfliktu zbrojnego, jak np. używanie do tłumienia demonstracji gazów łzawiących ${ }^{25}$.

Trudno uchwycić moment, w którym dochodzi do przekształcenia się stanu wewnętrznych napięć i niepokojów w konflikt zbrojny. MTKJ w orzeczeniu Boškoski \& Tarčulouski wskazał na zestaw elementów stanowiących o zaistnieniu konfliktu zbrojnego, a są to m.in. często dokonywane akty przemocy, w które zaangażowane są znaczne siły wojskowe, nie tylko zaś policyjne; dochodzi również wówczas do użycia broni ciężkiej; walki obejmują znaczny obszar, zajmowany przez dane grupy zbrojne, a spora część ludności cywilnej jest zmuszona opuścić swoje domostwa; notowana jest też wysoka liczba osób rannych i zabitych $^{26}$.

Już powyższe stwierdzenia pozwalają nam na wskazanie tych elementów, które mogłyby zostać wykorzystane w trakcie wojny hybrydowej. Należy bowiem uznać, że kryteria zakwalifikowania danej sytuacji jako wewnętrznego konfliktu zbrojnego są bardziej wymagające niż w przypadku konfliktu międzynarodowego. Warto zauważyć, że podczas kryzysu krymskiego, od którego notabene rozpoczęła się medialna kariera pojęcia "wojna hybrydowa”, dochodziło jedynie do sporadycznych aktów przemocy, co mogłoby sugerować stan wewnętrznych napięć i niepokojów ${ }^{27}$. Tym bardziej że Federacja Rosyjska aż do zakończenia operacji przejęcia półwyspu zaprzeczała swojemu zaangażowaniu

${ }^{24}$ The Prosecutor $v$. Dusko Tadic, Decision on the Defence Motion for Interlocutory Appeal on Jurisdiction, ICTY, IT-94-1-A, 2 October 1995, para. 70; M. Shaw, Prawo międzynarodowe, Warszawa 2006, s. 674.

${ }^{25}$ B. Janusz-Pawletta, Międzynarodowe prawo humanitarne konfliktów zbrojnych, Warszawa 2013, s. 30.

${ }^{26}$ Prosecutor v. Ljube Boškoski and Johan Tarčulouski, ICTY, IT-04-82-T, July 2008, § 177.

${ }^{27}$ Szerzej na ten temat: P. Ochmann, J. Wojas, Zagadnienia prawne rosyjskiej interwencji na Krymie, „Sprawy Międzynarodowe” 2016, nr 1, s. 89-110. 
zbrojonemu na terytorium Ukrainy ${ }^{28}$. Z punktu widzenia agresora taka sytuacja jest korzystna, bowiem konflikt wewnętrzny, a tym bardziej stan wewnętrznych napięć i niepokojów, pozwala na uniknięcie odpowiedzialności za podejmowanie działań zbrojnych przeciw innemu państwu. Tym samym niejasność rozgraniczenia między stanem wewnętrznych napięć i niepokojów a konfliktem wewnętrznym powoduje, że najeźdźca będzie starał się imitować takie sytuacje m.in. poprzez działania poniżej progu wojny - jednej z cech charakterystycznych dla wojny hybrydowej ${ }^{29}$. Państwo ingerujące musi oczywiście liczyć się z odpowiedzią społeczności międzynarodowej, ze względu na zaangażowanie (ingerencję) w sprawy wewnętrzne innego państwa ${ }^{30}$, jednakże w takiej sytuacji mało prawdopodobne jest uznanie przez społeczność międzynarodową prawa ofiary takich ingerencji do działań w ramach samoobrony.

W tym miejscu należy wskazać, że większość doktryny nie zgadza się, aby skorzystać z tego prawa w przypadku starć o niskim stopniu intensywności. Uznaje się tym samym, że napaść zbrojna, będąca najpoważniejszą odmianą bezprawnego użycia siły, może zostać uznana za moment, w którym państwo napadnięte może skorzystać z prawa do samoobrony. O tym, kiedy dochodzi do napaści zbrojnej, decyduje znaczna skala ataku obcego państwa ${ }^{31}$. Za stanowiskiem tym wydaje się opowiadać także orzecznictwo, w szczególności Międzynarodowego Trybunału Sprawiedliwości (MTS), który jest raczej powściągliwy w przyznawaniu prawa do samoobrony ofiarom drobnych ataków ${ }^{32}$. Opinię tę

${ }^{28}$ Żołnierze rosyjscy występowali w zielonych mundurach bez oznaczeń, stąd ich nieformalna nazwa "zielone ludziki". Podawali się również za członków lokalnej paramilitarnej organizacji Samoobrona Krymu. Zob. S.R. Reeves, D. Wallace, The Combatant Status of the "Little Green Men" and Other Participants in the Ukraine Conflict, "International Law Studies" 2015, vol. 91, s. 392-396; T. Srogosz, Status prawny nieoznakowanych żolnierzy w wojnie hybrydowej, "Sprawy Międzynarodowe” 2015, nr 4, s. 93-106.

${ }^{29} \mathrm{~K}$. Wąsowski, op. cit., s. $42-43$.

${ }^{30}$ Co stanowi naruszenie art. 2 ust. 7 Karty Narodów Zjednoczonych (Dz.U. 1947 Nr 23, poz. 90).

${ }^{31}$ Między innymi: O. Corten, The Law Against War: The Prohibition on the Use of Force in Contemporary International Law, Portland 2010, s. 403; A. Randelzhofer, Article 51, w: The Charter of United Nations, ed. by B. Sima, Oxford 2002, s. 790; S.A. Alexandrov, Self-Defense Against the Use of Force in International Law, Hague 1996, s. 110.

${ }^{32} \mathrm{O}$ konieczności odróżnienia drobnych incydentów zbrojnych od cięższych przypadków użycia siły MTS wspominał m.in. w sprawach: Nikaragui (Military and Paramilitary Activities in and against Nicaragua, Nicaragua v. United States of America, Jurisdiction and Admissibility, I.C.J. Reports 1986, p. 14, ICJ, 27 June 1986, § 191), ataku USA na irańskie platformy wiertnicze (Oil Platforms, Islamic Republic of Iran v. United States of America, 
podzielają także powoływane komisje badawcze do spraw określonych konfliktów, jak np. w Gruzji ${ }^{33}$, a nawet same państwa w swojej prakty$\mathrm{ce}^{34}$. Nierozwiązanym dotąd problemem jest jednak brak określonego przez orzecznictwo czy doktrynę progu intensywności starć, od którego można by mówić o napaści zbrojnej, a nie innej formie użycia siły. Biorąc pod uwagę tematykę niniejszej pracy, należy także zaznaczyć, że dominujące stanowisko wykorzystywane jest również jako pretekst do unikania odpowiedzialności przez państwo za swoje wrogie działania wobec innego państwa. W związku z tym część autorów opowiada się za tym, aby nawet drobny incydent graniczny upoważniał państwo do działań zbrojnych w samoobronie. Ich zdaniem kryteria natychmiastowości, konieczności i proporcjonalności odpowiedzi zbrojnej w ramach samoobrony wynikające z prawa zwyczajowego są wystarczającym zabezpieczeniem przed ewentualną eskalacją konfliktu ${ }^{35}$.

Warto również zaznaczyć, że ostatecznie zaangażowanie w operacji krymskiej przez Rosję znacznej liczby żołnierzy nakazuje spoglądać na tę sytuację jako na początek międzynarodowego konfliktu zbrojnego ${ }^{36}$.

\section{Zaistnienie konfliktu wewnętrznego a kontrola państwa nad jedną ze stron}

Warto także zauważyć, że konflikt zbrojny na Ukrainie po zakończeniu kryzysu krymskiego przybrał formę przypominającą właśnie konflikt

ICJ Reports 2003, § 51) czy ataku Ugandy na Kongo (Armed Activities on the Territory of the Congo, Democratic Republic of the Congo v. Uganda, ICJ Reports 2005, § 146). Zob. J. Green, The International Court of Justice and Self-Defence in International Law, Portland 2009, s. 33-41.

${ }^{33}$ Independent International Fact-Finding Mission on the Conflict in Georgia, Report, vol. II, September 2009, s. 244.

${ }^{34}$ Do tej kwestii odróżnienia incydentów granicznych od konfliktu zbrojnego odwoływała się np. Japonia przed Trybunałem tokijskim w 1945 r. dla określenia swoich walk z ZSRR w 1938 i w 1939 r. Zob. M. Kowalski, Prawo do samoobrony jako środek zwalczania terroryzmu międzynarodowego, Warszawa 2013, s. 131.

${ }^{35}$ Zob. T. Gazzini, The Changing Rules on the Use of Force in International Law, Manchester 2005, s. 138; R. Higgins, Problems and Process: International Law and How We Use It, Oxford 2004, s. 251; M. Kowalski, op. cit., s. 82.

${ }^{36} \mathrm{~W}$ tym miejscu trzeba zaznaczyć, że z powodu niskiej intensywności należałoby odrzucić opcję o zaistnieniu na Ukrainie (w trakcie kryzysu krymskiego) konfliktu wewnętrznego między siłami rządowymi a Samoobroną Krymu. Dodatkowym czynnikiem jest efektywna kontrola, jaką Rosjanie sprawowali nad ową formacją. Kwestia ta będzie jednak szerzej omawiana w kolejnych fragmentach tekstu. Zob. P. Ochmann, J. Wojas, Zagadnienia prawne..., s. 89-110. 
wewnętrzny. Na części obszaru donieckiego i ługańskiego powstały separatystyczne republiki, dysponujące własnymi siłami zbrojnymi, które do dziś prowadzą działania zbrojne przeciw siłom ukraińskim ${ }^{37}$. Prima facie była to sytuacja konfliktu wewnętrznego, której imitowanie przez rzeczywistego najeźdźcę może być dosyć trudne, lecz jednocześnie, biorąc pod uwagę kryteria wojny hybrydowej, może również przynieść wiele korzyści agresorowi.

We wspomnianym już orzeczeniu MTKJ w sprawie Tadić stwierdzono, że nawet poważne starcia zbrojne nie są wystarczającym powodem do uznania danej sytuacji za konflikt wewnętrzny, jeżeli mają one charakter krótkotrwały. W doktrynie (bardziej w kategoriach wyjątku) tak traktowane jest rozstrzygnięcie w tzw. sprawie La Tablada, podjęte przed Międzyamerykańską Komisję Praw Człowieka. Dotyczyło ono incydentu, jaki miał miejsce w nocy z 23 na 24 stycznia 1989 r., gdy 42 uzbrojonych ludzi zaatakowało bazę wojskową La Tablada w Argentynie. W wyniku walk trwających ok. 30 godzin zginęło 29 napastników i kilku żołnierzy. Międzyamerykańska Komisja Praw Człowieka (MKPC) stwierdziła, że skala intensywności tego starcia, mimo jego ograniczenia czasowego i geograficznego, pozwala na uznanie tych walk za wewnętrzny konflikt zbrojny, co powoduje, że w takiej sytuacji mają zastosowanie normy międzynarodowego prawa humanitarnego. Odrzucono tym samym konieczność istnienia sytuacji, gdy mają miejsce poważne operacje wojskowe, a ścierające się grupy kontrolują część terytorium ${ }^{38}$.

Choć stanowisko MKPC nie zyskało uznania, to niewątpliwie wiele trudności sprawia uchwycenie momentu, w którym dany konflikt można uznać za "przedłużający się”. Jedną z proponowanych metod oceny tego jest analiza konfliktu od jego rozpoczęcia do zakończenia ${ }^{39}$. Jednak w przypadku konfliktów ciągle trwających jest to sposób mało użyteczny. Najrozsądniejsze w tym kontekście wydaje się stanowisko zaprezentowane m.in. przez Międzynarodowy Trybunał Karny, który w orzeczeniu Lubanga powiązał stan "przedłużającego się" charakteru

${ }^{37} \mathrm{O}$ regularnych naruszeniach rozejmu informuje m.in. przebywająca tam misja OBWE. Zob. http://www.osce.org/ukrainecrisis\#omreports (dostęp: 5 I 2018).

${ }^{38}$ J.C. Abella v. Argentina, November 18, 1997, OEA/Ser.L/V/II.98 doc. 6 rev. 13 April 1998, § 156; P. Grzebyk, Classification of the Conflict Between Ukraine and Russia in International Law (Ius Ad Bellum and Ius in Bello), "Polish Yearbook of International Law” 2014, vol. 24 , s. 51.

${ }^{39}$ K. Huszti Orban, N. Kalandarishvili-Mueller, Is it a Bird? Is it a Plane? Is it an Armed Conflict? - The Classification of the Situation in Syria, "Journal of International Law" 2012, no. 1 , s. $8-9$. 
konfliktu zbrojnego $\mathrm{z}$ istnieniem zdolności walczących grup do dokonywania długoterminowych operacji zbrojnych ${ }^{40}$.

Przeprowadzenie takich operacji związane jest także z innym czynnikiem. Zarówno zaznaczone powyżej orzecznictwo, jak i II PD KG wskazuje na konieczność sprawowania w konflikcie wewnętrznym przez oddziały rebelianckie takiego stopnia kontroli nad określonym terytorium państwa, które pozwalałoby na prowadzenie stamtąd "ciągłych i spójnych" operacji zbrojnych. Są to ponownie określenia nieostre, lecz kontrolowanie określonego obszaru wydaje się wykluczać sytuację nieustannego rozproszenia sił i działania w ukryciu.

Powyższe uwagi łączą się z kolejnym elementem charakteryzującym konflikt wewnętrzny, jakim jest określony stopień organizacji grup zbrojnych zaangażowanych w walki. Wskazówki pozwalające ocenić stopień organizacji grup zbrojnych biorących udział w wewnętrznym konflikcie zbrojnym nakreślił MTKJ w orzeczeniu Prosecutor v. Limaj, Bala, and Musliu, rozpatrujący status Armii Wyzwolenia Kosowa. Trybunał uznał, że strona konfliktu zbrojnego powinna posiadać "oficjalną, wspólną strukturę dowódczą, sztab, wyznaczone strefy działania". W praktyce sprowadza się to, co nadmienił również MTKJ, do stabilności i efektywności działania oddziałów, rozwiniętej hierarchicznej struktury dowódczej, która zdolna jest do przeprowadzenia operacji na dużą skalę $e^{41}$.

Ponadto warto dodać, że analiza dwóch pierwszych artykułów regulaminu haskiego z 1907 r., które określają zakres stosowania prawa wojennego na oddziały ochotnicze i pospolitego ruszenia, wskazuje, iż doktryna uznaje, że istniejące w takich formacjach dowództwo nie ogranicza się tylko do kwestii operacyjnych, lecz niekoniecznie musi to oznaczać podporządkowanie dyscyplinarne ${ }^{42}$. Zarazem należy jednak zastrzec, że aktorzy niepaństwowi nie muszą charakteryzować się aż takim zaawansowaniem organizacyjnym jak siły rządowe, którym z tytułu tego, że reprezentują struktury państwowe, przysługuje domniemanie istnienia wysokiego stopnia zorganizowania ${ }^{43}$.

${ }^{40}$ Prosecutor v. Lubanga, Decision on the confirmation of charges, ICC-01/04-01/06803-tEN, § 233-234.

${ }^{41}$ Prosecutor v. Limaj, Bala, and Musliu, ICTY, Trial Chamber, IT-03-66, § 94-134.

${ }^{42}$ R. Bierzanek, Wojna a prawo międzynarodowe, Warszawa 1982, s. 132; zob. też przywoływana już Konwencja dotycząca praw i zwyczajów wojny lądowej.

${ }^{43}$ K. Huszti Orban, N. Kalandarishvili-Mueller, op. cit., s. 5; A. Cullen, The Threshold of Non-International Armed Conflict, w: idem, The Concept of Non-International Armed Conflict in International Humanitarian Law, Cambridge 2010. 
Z perspektywy państwa chcącego podejmować działania zbrojne przeciwko innemu państwu, już samo zaistnienie konfliktu wewnętrznego na takich zasadach może otwierać nowe możliwości. Należy do nich objęcie kontroli nad jedną ze stron walczących, bądź nawet stworzenie strony takiego konfliktu. Z tą ostatnią sytuacją mieliśmy do czynienia w przypadku konfliktu ukraińskiego. W przeciwieństwie jednak do tzw. kryzysu krymskiego, w trakcie którego żołnierze rosyjscy jako „zielone ludziki" podawali się za przedstawicieli Samoobrony Krymu ${ }^{44}$, w walkach na wschodzie Ukrainy przyjęto inną taktykę. Według niej główne starcia odbywały się między republikami separatystycznymi a siłami podległymi rządowi w Kijowie ${ }^{45}$. Kluczowa jednak była tutaj kontrola, jaką sprawowała Rosja nad siłami rebelianckimi. Z perspektywy prawa międzynarodowego przypisanie państwu odpowiedzialności za działania danej grupy budzi kontrowersje i jest dość trudne do wykrycia.

W tym kontekście należy zastrzec, że samo wysyłanie broni, wsparcie logistyczne czy szkoleniowe nie jest równoznaczne z przekształceniem danego konfliktu wewnętrznego w konflikt międzynarodowy. Jak stwierdził Międzynarodowy Trybunał Sprawiedliwości w orzeczeniu w sprawie Nikaragui z 1986 r., aby możliwe było przypisanie odpowiedzialności państwa za działania dokonywane przez daną grupę, musi istnieć kontrola efektywna. Przejawia się ona w sprawowaniu nadzoru przez państwo (w tzw. sprawie Nikaragui MTS rozpatrywał kwestię odpowiedzialności Stanów Zjednoczonych za działania partyzantki contras w tym kraju). W orzeczeniu wskazano, że w wypadku dokonania aktów zbrojnych przez aktora niepaństwowego, możliwe jest ich przypisanie innemu państwu, gdy to ono wysłało tego typu grupy lub działają one w jego imieniu, lub dokonane przez nie akty poczyniono przy znacznym zaangażowaniu tegoż państwa ${ }^{46}$. Trybunał ustalił jednak kryteria przypisania takich działań bardzo restrykcyjnie. Państwo odpowiada bowiem za działalność takich grup jedynie w przypadku, gdy sprawuje nad nimi „ścisłą i efektywną kontrolę"47. W praktyce oznacza to, że

${ }^{44}$ Szerzej zob. P. Ochmann, J. Wojas, Podstęp w czasie konfliktu zbrojnego, "Sprawy Międzynarodowe" 2016, nr 2, s. 27-40.

${ }^{45}$ Notowano również bezpośrednie zaangażowanie sił zbrojnych Federacji Rosyjskiej, głównie w czasie najcięższych starć, np. w sierpniu 2014 r. Zob. P. Ochmann, J. Wojas, Wspótczesne znaczenie aktu wypowiedzenia wojny w kontekście konfliktu na wschodzie Ukrainy, „Sprawy Międzynarodowe” 2015, nr 4, s. 93-105.

${ }^{46}$ Military and Paramilitary..., § 195.

${ }^{47}$ Ibidem, § 115. 
nadzoruje poszczególne działania takich formacji, a nie tylko wysyła broń czy okazuje wsparcie logistyczne, finansowe itp. ${ }^{48}$

Podobnego zdania była Komisja Prawa Międzynarodowego (KPM) w "Artykułach o odpowiedzialności państw za akty międzynarodowe”. $\mathrm{W}$ art. 8 tego dokumentu pt. "Działania kierowane lub kontrolowane przez państwo" określono, że możliwe jest przypisanie działań danego oddziału państwu, jeżeli działa on pod kierownictwem, kontrolą lub zgodnie z instrukcjami tego państwa ${ }^{49}$. W komentarzach KPM do "Artykułów” znalazło się również odwołanie do stanowiska MTS w sprawie Nikaragui ${ }^{50}$.

Pogląd o kontroli efektywnej spotkał się jednak ze sporą krytyką. Przede wszystkim przyjęcie tak restrykcyjnych kryteriów powoduje, że w warunkach wojennych przypisanie odpowiedzialności za działania danej grupy jest niezwykle trudne. To w konsekwencji może spowodować, że państwo-ofiara ataku, które nie może wykazać efektywnej kontroli, zostanie pozbawione możliwości skorzystania z prawa do samoobrony wobec rzeczywistego najeźdźcy ${ }^{51}$.

Wobec tego w 1999 r. w orzeczeniu Tadić Izby Apelacyjnej MTKJ sformułowano nowe stanowisko w kwestii przypisania państwu działania grup zbrojnych. Podobnie jak MTS, Trybunał ten uznał za niewystarczające dla przypisania jedynie wsparcia finansowego, logistycznego czy szkoleniowego. Natomiast warunkiem koniecznym dla przypisania danego działania jest istnienie pewnego stosunku posłuszeństwa i podległości między państwem a daną grupa, co przejawia się w koordynacji i sprawowaniu ogólnej pieczy nad działalnością tej grupy. Należy jednak zastrzec, że nie jest przy tym wymagane, aby państwo nadzorowało każde działanie danej grupy (tzw. kontrola ogólna) ${ }^{52}$.

\footnotetext{
${ }^{48}$ Ibidem, § 195.
}

${ }^{49}$ Responsibility of States for Internationally Wrongful Acts, "Text reproduced as it appears in the annex to General Assembly resolution 56/83 of 12 December 2001, and corrected by document A/56/49 (Vol. I) / Corr. 4", http://www.soas.ac.uk/cedepdemos/000_P514_IEL_K3736 Demo/treaties/media/2001\%20UN\%20internationally\%20 wrongful\%20acts.pdf (dostęp: 13 VI 2016).

${ }^{50}$ Wskazano również na pogląd wyrażony przez MTKJ w orzeczeniu Tadić, jednakże zaznaczono, że tamta sprawa nie dotyczyła odpowiedzialności państwa, ale odpowiedzialności kryminalnej jednostki. Zob. Draft Articles on Responsibility of States for Internationally Wrongful Acts, with commentaries, "Text adopted by the International Law Commission at Its fifty-third session, in 2001, and submitted to the General Assembly as a part of the Commission's report covering the work of that session (A/56/10)", art. 8, § 4-5, http://legal. un.org/ilc/texts/instruments/english/commentaries/9_6_2001.pdf(dostęp: 13 VI 2016).

${ }^{51}$ M. Kowalski, op. cit., s. 173-175.

52 Prosecutorv. Dusko Tadic, IT-94-1, ICTY Appeals Chamber, 15 July 1999, § 131-147. 
Ponadto pogląd MTKJ nie spowodował zmiany linii orzeczniczej MTS. W 2007 r. Trybunał ten we wspomnianym już wyroku w sprawie zastosowania Konwencji przeciwko ludobójstwu podtrzymał swoje stanowisko odnośnie do standardów przypisania odpowiedzialności w ramach kontroli efektywnej. W tym orzeczeniu MTS uznał, że działań oddziałów bośniackich Serbów w Srebrenicy nie można, z powodu niewystarczającego stopnia kontroli, przypisać Federacyjnej Republice Jugosławii. Dodatkowo zaznaczono, że art. 8 KPM jest odzwierciedleniem normy zwyczajowej. Podnoszono także przekroczenie granic jurysdykcji przez MTKJ, zadaniem tego organu jest bowiem badanie odpowiedzialności prawnej jednostki, a nie państw. Z drugiej strony, MTS odróżnił sytuację określenia stanu międzynarodowego konfliktu zbrojnego od odpowiedzialności państwa za działania niepaństwowych grup zbrojnych i przyznał możliwość w tym pierwszym przypadku zastosowania kryteriów kontroli ogólnej dla zbadania powiązań między grupami nieregularnymi a danym państwem ${ }^{53}$. Tym samym, zdaniem Trybunału, kwestia pociągnięcia do odpowiedzialności państwa za działania aktorów niepaństwowych powinna rozstrzygać się na podstawie standardów kontroli efektywnej, natomiast przy badaniu charakteru konfliktu zbrojnego może to mieć miejsce na podstawie kontroli ogólnej ${ }^{54}$.

Odnosząc powyższe rozważania do sytuacji wojny hybrydowej, należy wskazać dwa elementy często występujące w tego typu konfliktach, czyli użycie sił nieregularnych oraz działanie przez pośredników. Tym samym bardzo prawdopodobne jest, że konflikt wewnętrzny w rzeczywistości okazuje się konfliktem międzynarodowym (wojna na Ukrainie $^{55}$ ). Jednakże wykrycie takiej sytuacji jest dosyć trudne. Tym samym mamy tutaj dość korzystną dla agresora, wskazywaną przez badaczy w przypadku wojen hybrydowych, sytuacje prowadzenia wojny przez pośrednika, czyli sytuację, w której najeźdźca próbuje uniknąć swojej odpowiedzialności za bezprawne użycie siły, w istocie kamuflując własne działania ${ }^{56}$. Warto zauważyć, że dzięki tej taktyce Federacja Rosyjska konsekwentnie odmawia poczuwania się do odpowiedzialności za bycie stroną konfliktu zbrojnego na Ukrainie.

${ }^{53}$ Application of the Convention on the prevention and punishment of a crime of genocide $\S 403-404$.

${ }^{54}$ M. Kowalski, op. cit., s. 180-183.

${ }^{55}$ Zob. W. Lewicki, Wojna hybrydowa na Ukrainie - nowa jakość prowadzenia wojny, w: Wojna hybrydowa na Ukrainie. Wnioski i rekomendacje, pod red. B. Packa i J.A. Grochowskiej, op. cit.

${ }^{56}$ K. Wąsowski, op. cit., s. 42-43. 


\section{Umiędzynarodowiony konflikt wewnętrzny}

Kwestia kontroli państwa nad jedną z grup będących stroną konfliktu wewnętrznego nie jest klasyczną formą umiędzynarodowionego konfliktu wewnętrznego. To pojęcie nie ma legalnej definicji i należy je zrekonstruować na podstawie praktyki państw ${ }^{57}$. Agresor może włączyć się w trwający konflikt wewnętrzny poprzez bezpośrednie zaangażowanie sił zbrojnych danego państwa. Konsekwencje takiego kroku mogą być różne w zależności od intencji interwenta. W $1996 \mathrm{r}$. MTKJ w sprawie Rajić zaznaczył, że aby można było mówić o umiędzynarodowionym konflikcie, interwencja obcego państwa musi mieć charakter "ciągły i znaczący" ${ }^{\prime \prime}$.

Nie każde dołączenie się do istniejącego konfliktu zbrojnego musi mieć koniecznie charakter bezprawny. Dopuszczalne jest zaangażowanie się obcych sił zbrojnych w konflikt wewnętrzny za zgodą legalnego rządu ${ }^{59}$. W przypadkach odwrotnych, czyli wsparcia rebeliantów przez obce państwo, należy taką interwencję uznać za niezgodną z prawem międzynarodowym. Jednak w wypadku uznania strony rozłamowej konfliktu wewnętrznego za stronę wojującą taka interpretacja wydaje się nieuzasadniona. Prowadzi to bowiem do nieuprawnionego uprzywilejowania strony legalnego $\mathrm{rzacdu}^{60}$. Ponadto interwencja po stronie rebelianckiej na jej prośbę wydaje się mieć legalne podstawy, także wtedy, gdy mamy do czynienia z ludem walczącym z reżimem kolonialnym, rasistowskim lub obcą okupacją. Taka sytuacja już sama w sobie, na podstawie art. 1 ust. 4 I PD KG ${ }^{61}$, jest bowiem traktowana jako konflikt międzynarodowy ${ }^{62}$.

Państwo interweniujące może równie dobrze nie opowiadać się za żadną ze stron konfliktu wewnętrznego i podjąć walkę zarówno

${ }^{57}$ J.G. Stewart, Towards a Single Definition of Armed Conflict in International Humanitarian Law: A Critique of Internationalized Armed Conflict, "International Review of the Red Cross" 2003, no. 850, June, s. 313-349.

${ }^{58}$ Prosecutor v. Rajić, "Review of the Indictment Pursuant to Rule 61", IT-95-12-R61, ICTY, 13 September 1996, § 21.

${ }^{59}$ R. Bierzanek, Wojna a prawo międzynarodowe, s. 338.

${ }^{60}$ R. Bierzanek, J. Symonides, op. cit., s. 435.

${ }^{61}$ Protokół dodatkowy do konwencji genewskich z 12 VIII 1949 r., dotyczący ochrony ofiar międzynarodowych konfliktów zbrojnych, Genewa, 8 VI 1977 r. (Dz.U. 1992 Nr 41, poz. 175, załącznik).

${ }^{62}$ Więcej na ten temat: M. Marcinko, Bojownicy o wolność czy terroryści?: członkowie ruchów narodowowyzwoleńczych w świetle międzynarodowego prawa humanitarnego, „Polski Rocznik Praw Człowieka i Prawa Humanitarnego" 2010, nr 1, s. 208. 
z siłami rządowymi, jak i rozłamowymi. Oznacza to znaczne skomplikowanie pod względem prawnym sytuacji w trwającym konflikcie wewnętrznym. Przede wszystkim chodzi tu o kwestię obowiązywania norm międzynarodowego prawa humanitarnego. Jak już zostało wspomniane, w przypadku konfliktu wewnętrznego nie ma zastosowania większość przepisów międzynarodowego prawa humanitarnego, lecz przede wszystkim obowiązuje prawo krajowe oraz prawa człowieka. Zakładając tym samym zaistnienie umiędzynarodowionego konfliktu wewnętrznego, trzeba rozpatrzyć możliwość rozróżnienia w jego trakcie czterech stosunków prawnych ${ }^{63}$ :

1. między walczącymi wojskami interweniującymi,

2. między wojskami rządowymi a wojskami interweniującymi,

3. między wojskami interweniującymi a rebeliantami,

4. między wojskami rządowymi a rebeliantami ${ }^{64}$.

Podział ten ma ułatwiać ustalenie, w jakiej części w takim konflikcie może mieć zastosowanie międzynarodowe prawo humanitarne. W dwóch pierwszych sytuacjach proponuje się zastosowanie go w całości, natomiast w ostatnim przypadku jedynie w skali przewidzianej dla konfliktów wewnętrznych. Kontrowersję budzi trzeci przypadek $^{65}$. Przeważa jednak opinia, aby sytuację taką traktować w sposób tożsamy z konfliktem wewnętrznym ${ }^{66}$. Niemniej w trakcie zawieruchy wojennej powoduje to dodatkowe komplikacje i wzmacnia chaos w danym państwie, co jest również jednym z celów wojny hybrydowej ${ }^{67}$.

Od powyższych sytuacji należy jednak odróżnić występowanie konfliktu międzynarodowego obok konfliktu wewnętrznego. Z taką sytuacją mamy do czynienia, gdy agresor nie wspiera sił rozłamowych w danym państwie, ale walczy jedynie z siłami rządowymi. Tutaj jednak sytuacja

${ }^{63}$ W podobnym duchu wypowiedział się m.in. MTS. Zob. Military and Paramilitary..., § 219; R. Bierzanek, J. Symonides, op. cit., s. 435.

${ }^{64}$ Ten teoretyczny podział, z pozoru trudny do zaistnienia i rozgraniczenia w praktyce, miał przynajmniej częściowe odzwierciedlenie w rzeczywistości, w czasie wspomnianych już wojen w Jugosławii.

${ }^{65}$ R. Bierzanek, op. cit., s. 338-339.

${ }^{66}$ Internationalized Internal Armed Conflict, ICRC, https://casebook.icrc.org/glossary/ internationalized-internal-armed-conflict (dostęp: 5 I 2018).

${ }^{67}$ Podawanym przez R. Bierzanka i J. Symonidesa przykładem wybiegu stron walczących z rebeliantami jest przekazywanie pojmanych przez siły obcego państwa powstańców oddziałom rządowym, co powoduje pozbawienie ich praw jeńców wojennych. Zob. R. Bierzanek, J. Symonides, op. cit., s. 435. 
jest dużo bardziej klarowna, gdyż istnieje wyraźne rozgraniczenie między stanem stosowania przepisów międzynarodowego prawa humanitarnego i tych właściwych dla konfliktu wewnętrznego ${ }^{68}$.

\section{Działanie aktora niepaństwowego z terytorium innego państwa}

Inną możliwością zaangażowania państwa w konflikt wewnętrzny jest umożliwienie grupom zbrojnym atakowanie ze swego terytorium obszaru innego państwa. Taka sytuacja miała miejsce w przypadku wojny lipcowej w 2006 r. Z perspektywy państwa, które ma zamiar zaatakować inne, takie działanie wydawać się może korzystne, bowiem nie musi sprawować kontroli nad daną grupa, lecz po prostu nie będzie utrudniać jej działalności. Ponadto sama grupa zbrojna może być stroną konfliktu wewnętrznego, co pozwala na utrzymywanie pozorów konfliktu wewnętrznego, a to z kolei umożliwia danemu państwu uniknięcie odpowiedzialności międzynarodowej za działania przeciw innemu państwu.

Jest to również przykład konfliktu przez pośrednika (proxy war), w którym koszty państwa-rzeczywistego agresora są ograniczone do minimum. $Z$ perspektywy prawnej państwo, na terytorium którego działa aktor niepaństwowy, nie jest jednak zwolnione z odpowiedzialności za napaść zbrojną na inne państwo. Zgodnie z prawem międzynarodowym państwo jest zobowiązane do zapewnienia, że na jego terytorium nie będą prowadzone działania zbrojne przeciw innemu państwu. Konsekwencją tego jest obowiązek uniemożliwienia działalności aktora niepaństwowego ${ }^{69}$.

Kontrowersje budzi jednak przyznanie ofierze ataku możliwości dokonania legalnej zbrojnej odpowiedzi w ramach prawa do samoobrony przeciwko państwu, na którego terytorium działa aktor niepaństwowy. Z travaux preparatoires Karty Narodów Zjednoczonych wynika, że twórcy tego dokumentu w pracach nad art. 51 przyznającym ofierze

${ }^{68} \mathrm{Z}$ takim zapętleniem mamy do czynienia m.in. w przypadku trwającego obecnie konfliktu w Syrii, na który nakłada się konflikt wewnętrzny między siłami reżimu Baszara al-Asada z rebeliantami, walka międzynarodowej koalicji z tzw. Państwem Islamskim, starcia Turcji z oddziałami kurdyjskimi. Część sił zewnętrznych współpracuje przy tym z różnymi stronami konfliktu wewnętrznego (np. Rosja z wojskami Asada, a Stany Zjednoczone z rebeliantami). Zob. T.D. Gill, Classifying the Conflict in Syria, "International Law Studies" 2016, vol. 92, s. 354-379.

${ }^{69}$ Kwestia ta została poruszona m.in. w wyroku MTS w sprawie cieśniny Korfu z 1949 r. Zob. Corfu Channel Case, Judgment of April 9th, 1949, I.C.J. Reports 1949, s. 22. 
napaści prawo do działań samoobronnych odnosili się do relacji między państwami ${ }^{70}$. W takim przypadku wątpliwe wydaje się uznanie aktora niepaństwowego za samoistne źródło napaści zbrojnej, które upoważniałoby do ataku na terytorium innego państwa jedynie ze względu na to, że stamtąd działa aktor niepaństwowy.

Ta interpretacja została jednak porzucona w 2001 r. w związku z interwencją Stanów Zjednoczonych na Afganistan. Wówczas Rada Bezpieczeństwa ONZ przyjęła rezolucje 1368 i 1373 przyznające Stanom Zjednoczonym możliwość ataku baz Al-Kaidy na terytorium Afganistanu właśnie w odwołaniu do prawa do samoobrony ${ }^{71}$. Od tego momentu możliwość reakcji zbrojnej w ramach prawa do samoobrony zyskuje coraz większą aprobatę doktryny ${ }^{72}$. Warto jednak zaznaczyć, że państwo-ofiara napaści ma możliwość reakcji na atak wyłącznie w ramach zasad konieczności, proporcjonalności i natychmiastowości odpowiedzi zbrojnej. Tym samym atak na terytorium państwa, który umożliwia działania aktorowi niepaństwowemu na swoim terytorium przeciw innemu państwu, jest dość ograniczony, i to nie siły zbrojne państwa atakowanego są tu przeciwnikiem ${ }^{73}$.

Z tego względu dla państwa, któremu nie można przypisać odpowiedzialności za działania grup zbrojnych, lecz któremu zależy na osłabieniu innego państwa prowadzącego konflikt zbrojny, takie umożliwienie działań strony rebelianckiej na własnym terytorium jest niezwykle korzystne. Nawet przeprowadzenie ataku na jego terytorium może być bowiem skierowane wyłącznie na aktora niepaństwowego.

\section{Podsumowanie}

Przeprowadzone analizy potwierdzają założoną na początku artykułu hipotezę, że obowiązujące w trakcie umiędzynarodowionego konfliktu

${ }^{70}$ S. Alexandrov, op. cit., s. 77-93.

${ }^{71}$ S/RES/1368 (2001), 12 September 2001; S/RES/1373 (2001), 28 September 2001.

72 Między innymi: W. Czapliński, Odpowiedzialność za naruszenia prawa międzynarodowego w zwiazku z konfliktem zbrojnym, Warszawa 2009, s. 43-49; G. Molier, The War on Terror and Self-Defence Against Non-State Actors: An International Law Perspective, w: Terrorism: Ideology, Law and Policy, ed. by A. Ellian, G. Molier, D. Suurland, Dordrecht 2011, s. 316-328; J. Kranz, Wojna, pokój czy uspokajanie? Wspótczesne dylematy użycia sity zbrojnej, Warszawa 2006, s. 71; The Chatham House Principles of International Law on the Use of Force by States in Self-Defence, ed. by E. Wilmshurst, „International \& Comparative Law Quarterly" 2006, vol. 55, s. 963-972.

${ }^{73}$ M. Kowalski, op. cit., s. 188-202. 
wewnętrznego normy prawne stwarzają możliwości, które mogą zostać wykorzystane przez państwo prowadzące wojnę hybrydową i pozwolić mu na zrealizowanie założonych w niej celów, w tym uniknięcia odpowiedzialności za podejmowane działania.

Przede wszystkich zaangażowanie obcego państwa $\mathrm{w}$ tego typu konflikt może przybrać formę prowadzenia wojny przez pośrednika oraz wykorzystania oddziałów nieregularnych. Dotyczy to zwłaszcza sytuacji sprawowania przez państwo kontroli nad stroną konfliktu wewnętrznego. Należy również podkreślić, że już samo zaangażowanie sił zbrojnych obcego państwa w konflikt wewnętrzny w naturalny sposób komplikuje kwestie zastosowania norm prawnych w takim przypadku.

Trzeba także zwrócić uwagę na działania poniżej progu wojny. Dotyczy to zwłaszcza sytuacji imitowania czy inspirowania wewnętrznych napięć i niepokojów bądź zaangażowania na poziomie drobnych starć, w związku z którymi nie ma jednoznacznej odpowiedzi, czy ofierze takiego ataku przysługuje prawo reakcji zbrojnej w samoobronie.

Jedną z przyczyn takiego stanu jest nierównomierność w statusie prawnym między konfliktem międzynarodowym a niemiędzynarodowym. O ile w tym pierwszym mają w pełni zastosowanie normy międzynarodowego prawa humanitarnego, to $\mathrm{w}$ drugim przypadku stosuje się je jedynie częściowo. Pożądane byłoby zatem rozszerzenie zakresu prawa wojennego także na konflikty wewnętrzne. Ten postulat, choć wielokrotnie zgłaszany na arenie międzynarodowej, np. przez organizacje humanitarne, na razie ma niewielkie szanse realizacji.

Paradoksalnie wzrost bezpieczeństwa światowego mogłoby również przynieść zaakceptowanie przez orzecznictwo, państwa i doktrynę możliwości zbrojnej reakcji w ramach prawa do samoobrony także w przypadku działań "poniżej progu wojny”"74. Należy jednak zastrzec, że oczywiście reakcja taka musi nadal mieścić się w ramach kryteriów natychmiastowości, konieczności i proporcjonalności odpowiedzi.

Przyjęcie powyższych postulatów powinno doprowadzić do znacznego ograniczenia możliwości wykorzystania metod hybrydowych przez zewnętrznego interwenienta w wewnętrznym konflikcie zbrojnym.

${ }^{74}$ Postulat ten pojawia się także wśród części przedstawicieli doktryny. Zob.: T. Gazzini, op. cit., s. 138; R. Higgins, op. cit., s. 251; M. Kowalski, op. cit., s. 82. 


\section{A 'HYBRID WAR' AS AN EXAMPLE OF INTERNATIONALISATION INTERNAL CONFLICTS}

\section{S u m m a r y}

The paper deals with internal conflicts, their internationalisation and a hybrid war. In the 1990s many military conflicts could have been regarded as domestic conflicts or internationalised internal conflicts. According to the authors internationalised internal conflicts and a hybrid war have much in common. The purpose of the paper is to compare and confront distinctive characteristics of internationalised internal conflicts with the model of hybrid war. The authors scrutinize definitions of an internal, domestic conflict and a hybrid war, and the possibilities and likelihood of their occurrence. Finally the issue is analysed in terms of international public law.

'Hybrid war' is a term not defined in public international law. However it is commonly used not only by media and politicians, but also by academics in a scientific discourse. A question arises to what extent it is justified to use a term in the context of different military conflicts, like for instance the one in the East Ukraine that has been going on since 2015. Therefore it is necessary to explain what the term 'hybrid war' means. In order to do so, it is necessary to try to define the term. Its distinctive characteristics must be indicated. Then, many military conflicts will be analysed to determine whether they satisfy the requirements for qualifying them as a 'hybrid war' or an internationalised internal conflict.

The research leads to a conclusion that an internationalised internal conflict gives many opportunities for applying to it methods characteristic of a hybrid war. In the course of an internationalised internal conflict there are many ways in which the aggressor can evade international liability and the authors attempt to answer how to prevent this.

Keywords: hybrid war - international law- armed conflict - Ukraine 